\title{
Finite Element Model on Circular Concrete-encased CFST Columns under Compression and Torsion
}

\author{
Xiaoyou CHEN \\ School of Civil Engineering \\ Shenyang Jianzhu University \\ Shenyang, China
}

\author{
Qingxin REN \\ School of Civil Engineering \\ Shenyang Jianzhu University \\ Shenyang, China \\ e-mail: renqing xin@sjzu.edu.cn
}

\begin{abstract}
A three-dimensional (3D) finite element model (FEM) of circular concrete-encased CFST columns under axial compression and torsion was developed using the general finite element analysis (FEA) software ABAQUS. A total of 10 specimens with different axial load level and CFS T ratio were tested to verify the FEM. The comparison of the finite element predictions and the tests performed showed a reasonable agreement. The FEM was thus used to conduct the full range analysis and parametric analysis.
\end{abstract}

Keywords-concrete-encased CFST columns; circular section; compression and torsion; finite element analysis; experimental verification

\section{INTRODUCTION}

Concrete-encased concrete filled steel tube (CFST) is a type of steel-concrete composite section, which consists of inner CFST and outer reinforced concrete (RC) [1], as shown in Fig. 1. This type of composite member has an increasing trend in high-rise building and bridge structures in China. Concrete-encased CFST columns have higher ductility and shear resistance due to the existence of CFST compared to conventional RC columns [2-5]. Compared to the conventional CFST columns, concrete-encased CFST columns have higher fire resistance and better durability under corrosive environment due to the protection from the outer concrete of the CFST.

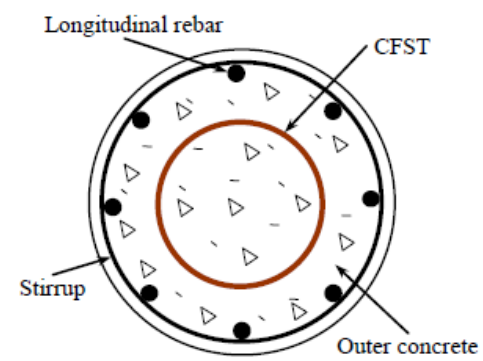

Figure 1. Cross-section of concrete-encased CFST

At present, research on composite columns is mainly in axial compression, pure bending and hysteresis, but relatively scarce in torsion, which brings great difficulties for the engineering design, construction and evaluation. Therefore, to understand the performance of concreteencased CFST columns under compression and torsion, a three-dimensional (3D) finite element model (FEM) was developed and a total of 10 specimens with different axial load level and CFST ratio were tested to verify the FEM.

\section{FINITE ELEMENT MODEL}

The commercial FEA package Abaqus/Standard module [6] was used in the numerical simulation. Some key is sues, such as such as the choice of element types, boundary conditions, material models and modelling of the steel tubeconcrete interface are described as following.

\section{A. Element Types and Meshes}

The end plates and concrete components including outer unconfined concrete and core concrete of CFST are simulated by eight-node 3D solid element with reduced integration (C3D8R). The steel tube is simulated by fournode conventional shell element (S4R). The rebars are simulated by using 3D 2-node truss elements (T3D2). The rebar elements are connected to outer concrete using the embedded element technique, where the translational degrees of freedom at the rebar node are eliminated. Different grid sizes are attempted to determine an appropriate mesh, as shown in Fig.2.

\section{B. Material Models}

1) Steel:

The elastic modulus and Poisson's ratio for steel were taken as $206000 \mathrm{~N} / \mathrm{mm} 2$ and 0.3 respectively. The fivestage stress-strain model provided by Han et al. [7] and the bi-linear line stress-strain model suggested by Zhao et al. [8] were used for the uniaxial stress-strain relation of the steel tube and the rebar respectively.

2) Concrete:

The damage plasticity model was applied to describe the constitutive behavior of concrete. The elastic modulus of concrete (Ec) was taken as 4730; poisson's ratio was taken as 0.2 . The uniaxial compressive stress-strain relations of the three kinds of concrete are different due to the different confined conditions. The uniaxial stress-strain models provided by Attard [9], Han et al. [7] and Han and An [10] were applied for outer unconfined concrete, outer confined concrete and core concrete of the CFST in the FEM. 


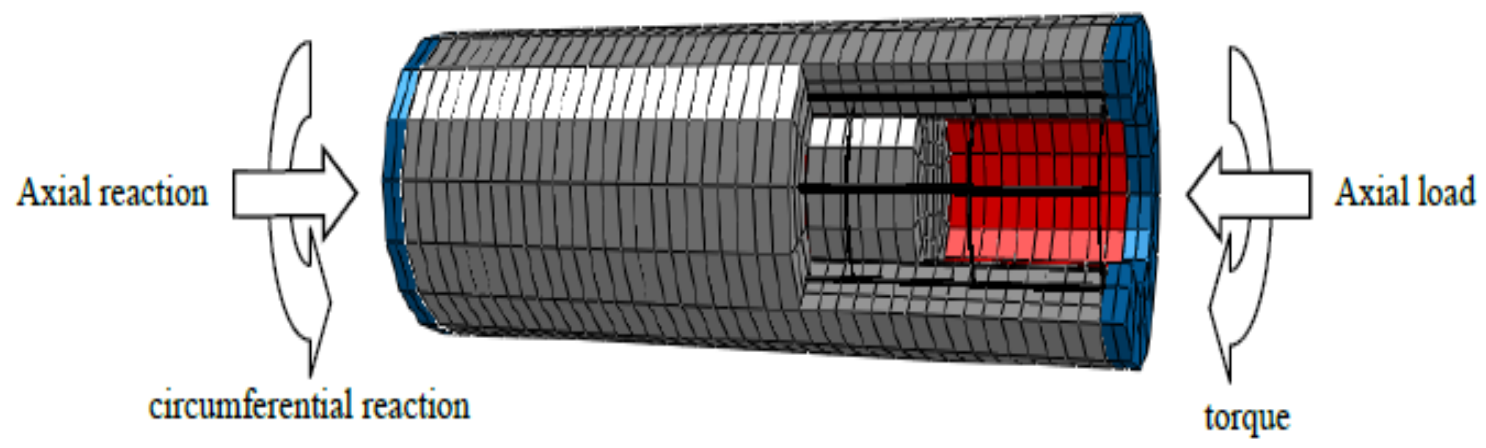

Figure 2. Finite element model

3) Concrete and Steel Interface Model:

"Hard contact" is chosen as the normal direction between steel tube and concrete including core and outer concrete. The bond stress between the steel tube and the concrete was determined according to Han and An [10].

4) Boundary conditions:

The end plate is as sumed to be elastic rigid block and the stiffness is large enough that the deformation in the whole loading can be neglected. The model fixed at one end, which limited the displacement of three directions; The other end is free to load, and reference point is used to couple with the end plate [11].

\section{Verification of the FEM}

The tests on circular concrete-encased CFST columns were used to verify the FEM, as listed in Table 1. Eight longitudinal rebars of diameter $11.6 \mathrm{~mm}$ was arranged uniformly as shown in Fig 1. The yield stress of the longitudinal rebar and the stirrup was $384 \mathrm{~N} / \mathrm{mm} 2$ and 326 $\mathrm{N} / \mathrm{mm} 2$ respectively.

The predicted results obtained by ABAQUS were compared to the test results as shown in Figs. 3 and 4. It can be seen that the predicted results agree well with the test results.

TABLE I. Summary of concrete-encased CFST columns

\begin{tabular}{|c|c|c|c|c|c|c|c|c|}
\hline \multirow{2}{*}{ No. } & \multirow{2}{*}{$\begin{array}{l}\text { Specimen } \\
\text { label }\end{array}$} & \multirow{2}{*}{$\begin{array}{l}\text { Cross-section } \\
D \times H(\mathrm{~mm})\end{array}$} & \multirow{2}{*}{$\begin{array}{l}\text { Steel tube } \\
d_{\mathrm{i}} \times t(\mathrm{~mm})\end{array}$} & \multicolumn{2}{|c|}{ Concrete grade } & \multirow{2}{*}{ Axial load level $n$} & \multirow{2}{*}{$\begin{array}{c}\text { CFST ratio } \\
\alpha_{\mathrm{cfst}}\end{array}$} & \multirow{2}{*}{$\begin{array}{c}\text { Reinforcement ratio } \\
\alpha_{1}(\%)\end{array}$} \\
\hline & & & & Outer & Core & & & \\
\hline 1 & ct1-1 & $200 \times 600$ & $120 \times 2.98$ & $\mathrm{C} 40$ & C60 & 0 & 0.6 & 2.95 \\
\hline 2 & ct1-2 & $200 \times 600$ & $120 \times 2.98$ & $\mathrm{C} 40$ & C60 & 0 & 0.6 & 2.95 \\
\hline 3 & ct2-1 & $200 \times 600$ & $120 \times 2.98$ & $\mathrm{C} 40$ & C60 & 0.3 & 0.6 & 2.95 \\
\hline 4 & ct2-2 & $200 \times 600$ & $120 \times 2.98$ & $\mathrm{C} 40$ & C60 & 0.3 & 0.6 & 2.95 \\
\hline 5 & ct3-1 & $200 \times 600$ & $120 \times 2.98$ & $\mathrm{C} 40$ & $\mathrm{C} 60$ & 0.6 & 0.6 & 2.95 \\
\hline 6 & ct3-2 & $200 \times 600$ & $120 \times 2.98$ & $\mathrm{C} 40$ & C60 & 0.6 & 0.6 & 2.95 \\
\hline 7 & ct4-1 & $200 \times 600$ & $100 \times 2.98$ & $\mathrm{C} 40$ & C60 & 0 & 0.5 & 2.63 \\
\hline 8 & ct $4-2$ & $200 \times 600$ & $100 \times 2.98$ & $\mathrm{C} 40$ & C60 & 0 & 0.5 & 2.63 \\
\hline 9 & ct5-1 & $200 \times 600$ & $80 \times 2.98$ & $\mathrm{C} 40$ & $\mathrm{C} 60$ & 0 & 0.4 & 2.42 \\
\hline 10 & ct5-2 & $200 \times 600$ & $80 \times 2.98$ & $\mathrm{C} 40$ & C60 & 0 & 0.4 & 2.42 \\
\hline
\end{tabular}




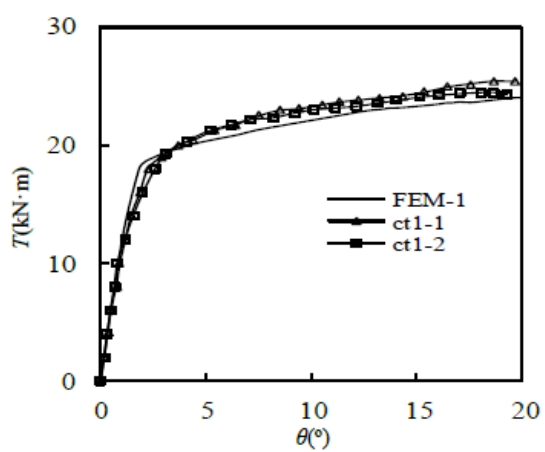

(a) ct 1

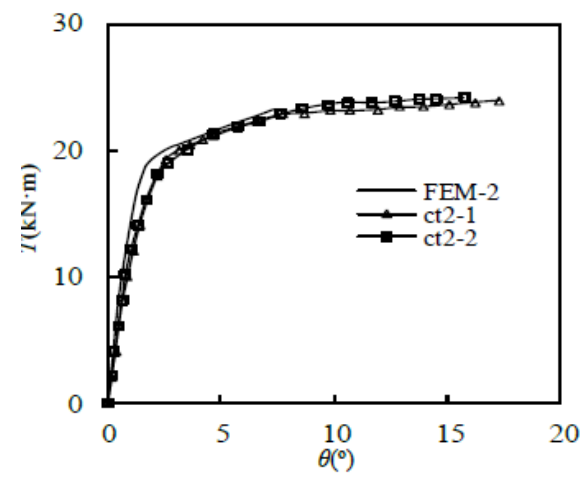

(b) ct2

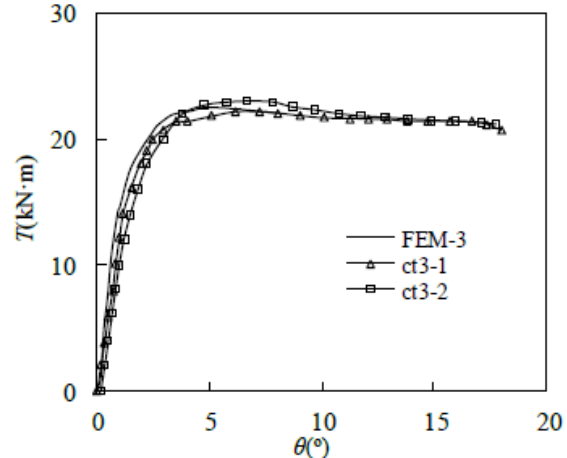

(c) ct3

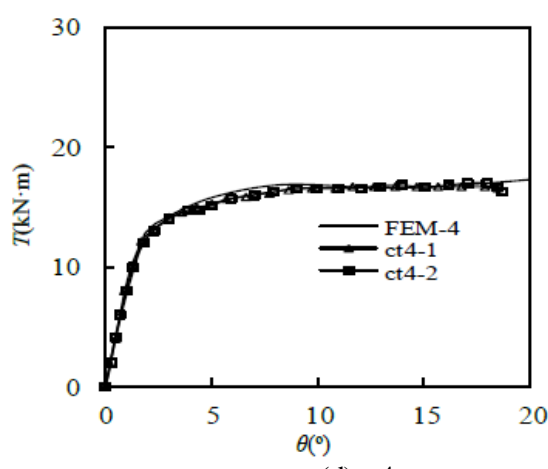

(d) ct4

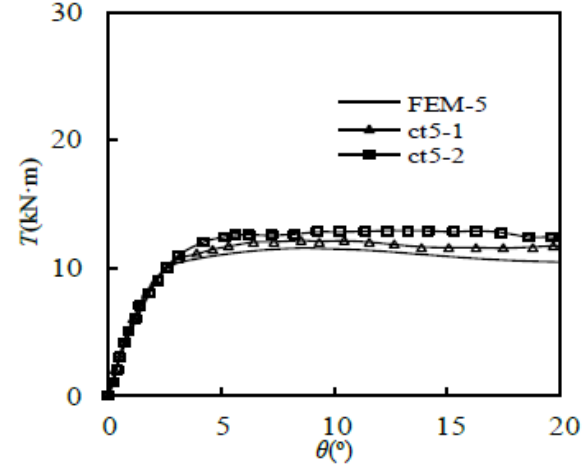

(e) ct5

Figure 3. Comparison of $\mathrm{T}-\theta$ curves

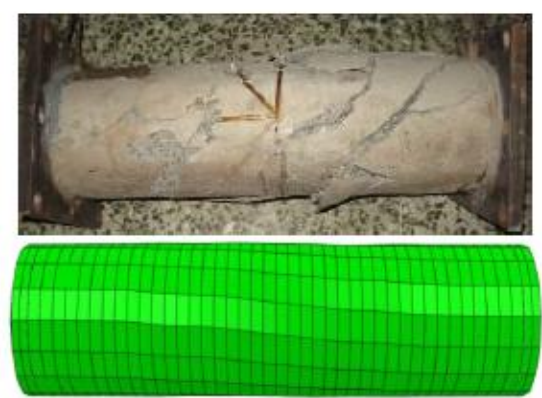

(a) ct 1-1

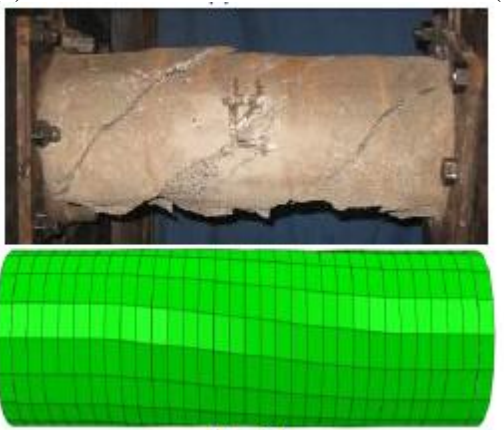

(d) ct4-1
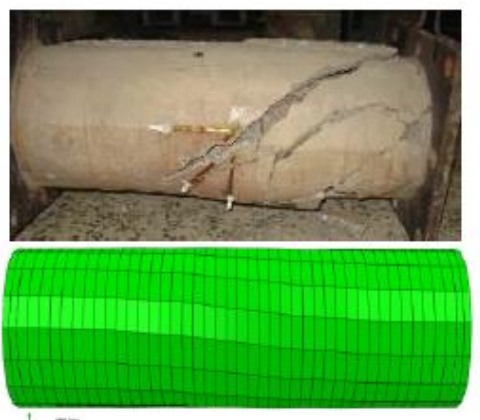

(b) ct2-2

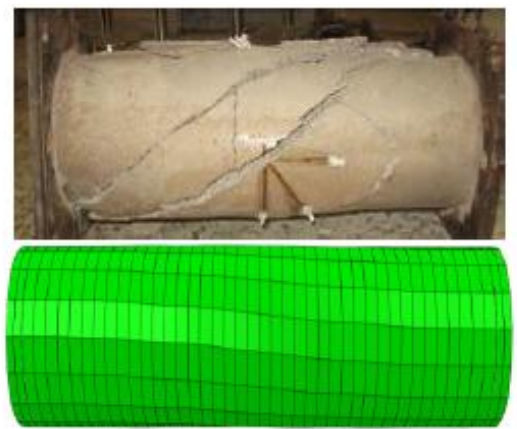

(c) ct3-1

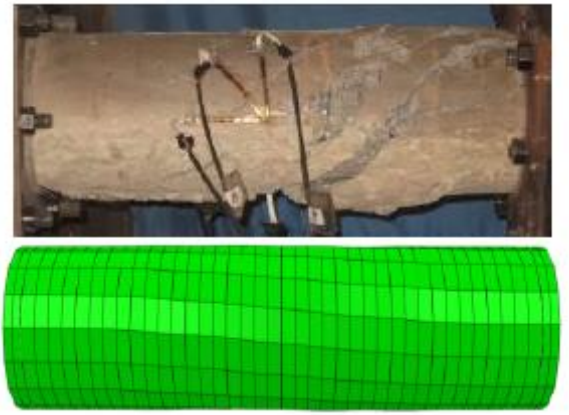

(d) ct5-2

Figure 4. Comparison of failure modes 


\section{CONCLUSIONS}

Based on the limited results of this study, the following conclusions can be drawn:

(1) The FEM which could be used to predict the behavior of concrete-encased CFST columns under axial compression and torsion was developed.

(2) The test results of concrete-encased CFST columns under axial compression and torsion were used to validate the FEM, good agreement was achieved.

\section{ACKNOWLEDGMENT S}

The research reported in the paper is part of the Project supported by the National Natural Science Foundation of China (NO. 51478275), the Program for Liaoning Excellent Talents in University (No. LR2015054) and the Project sponsored by "Liaoning BaiQianWan Talents Program" (No. 201559). The financial support is highly appreciated.

\section{REFERENCES}

[1] Han LH, Liao FY, Tao Z, Hong Z. Performance of concrete filled steel tube reinforced concrete columns subjected to cyclic bending. J Constr Steel Res 2009; 65(8-9): 1607-16.

[2] An YF, Han LH, Zhao XL. Experimental behaviour of box concreteencased CFST eccentrically loaded column. Mag Concr Res 2013; 65(20):1219-35
[3] Han LH, Li W, Bjorhovde R. Developments and advanced applications of concrete-filled steel tubular (CFST) structures: Members. J Constr Steel Res 2014; 100: 211-28.

[4] Han LH, Wang ZB, Xu W, Tao Z. Behavior of concrete-encased CFST members under axial tension. J Struct Eng ASCE 2016; 142(2): Paper ID: 04015149.

[5] Wang ZB, Han LH, Li W, Tao Z. Seismic performance of concreteencased CFST piers: Experimental study. J Bridge Eng ASCE 2016; 21(4): Paper ID: 040150721.

[6] Hibbitt, Karlson, Sorenson Inc. ABAQUS version 6.5: theory manual, users' manual, verification manual and example problems manual. Hibbitt, Karlson and Sorenson Inc.; 2005.

[7] Han LH, An YF. Performance of concrete-encased CFST stub columns under axial compression. J Constr Steel Res 2014; 93: 62-76.

[8] Zhao XM,Wu YF, Leung AYT. Analysis of plastic hinge regions in reinforced concrete beams under monotonic loading. Eng Struct 2012;34:466-82.

[9] Attard MM, Setunge S. Stress-strain relationship of confined and unconfined concrete. ACI Mater J 1996; 93(5):432-42.

[10] Han LH, Yao GH, Tao Z. Performance of concrete-filled thin-walled steel tubes under pure torsion. Thin-Walled Struct 2007; 45(1):24-36.

[11] Huang H, Han LH, Zhao XL. Investigation on concrete filled double skin steel tubes (CFDSTs) under pure torsion. J.Constr Steel Res 2013; 90: 221-34. 